\title{
Sustainable Tourism Development Through Improving the Role of Customary Village
}

\author{
I Gusti Ayu Purnamawati ${ }^{*}$ \\ ${ }^{1}$ Faculty of Economics, Ganesha University of Education, Indonesia
}

\section{A R T I C L E I N F O}

Article history:

Received 31 December 2020

Received in revised form 5 January 2021

Accepted 20 January 2021

Available online 25

February 2021

Keywords:

Customary, Development,

Tourism, Village

\begin{abstract}
A B S T R A C T
This study aims to analyze the potential of the Customary Village in tourism development, its position, and function in Bali Province. This research is a socio-legal study with a legal and case approach, legal analysis techniques in the form of legal hermeneutics and is analyzed through the theory of legal pluralism, and the concept of recognition of the Customary Law Community. This research was conducted in the area of Bali Province based on local wisdom with the concepts of Parahyangan, Pawongan, and Palemahan. The system and implementation of customary law, institutional Sabha Customary Village and Kerta Customary Village, custom advisory institutions, religion, traditions, arts, and culture, as well as local wisdom of indigenous peoples. Pasraman as an educational institution based on Hinduism for the development of identity, moral integrity, and quality of Balinese society, traditional village security institutions, and traditional village economic institutions by the principles and objectives of tourism, namely the welfare of the community. Especially the Krama Customary Village. The results showed that the Balinese Customary Village in tourism development is an autonomous Balinese customary institution, traditional cultural communities, indigenous peoples, and the collective identity of the people in Bali based on customary law to achieve common goals based on the Tri Hita Karana.
\end{abstract}

Copyright (C) Universitas Pendidikan Ganesha. All rights reserved.

\section{Introduction}

Community-based development is a development model that provides maximum opportunities for rural communities in this case one of the elements is the customary village to participate in tourism development. Community-based describes groups that meet in a community who work on personal initiative. Several community-based development activities try to formulate plans that will be implemented and those that are not implemented. Planning is the main focus of activities and refers to the process of reflecting on an action (Kent, 1981; Mansuri \& Rao, 2004). The community intended in the development of a Tourism Village is the local community or about a tourism village, it can be said as a customary village manner as specified in the Provincial Regulation of Bali No. 4 of 2019 concerning Indigenous Villages in Bali (hereinafter referred to as the Customary Village Regulation. Krama Desa Adat is a Hindu Balinese community (a registration system for traditional village manners) and registered as a member of the local traditional village, without intending to box the religion, that in fact, the main attraction of Bali tourism is the Balinese culture itself (Adnyani \& Purnamawati, 2020; Resen \& Dyatmikawati, 2016).

Dance, music, and architecture synergize with their religious rituals so that they become a special attraction for tourists (Arjawa \& Jayantiari, 2017; Chang \& Huang, 2014). The descendants of traditional villages are traditional institutions that maintain the traditions and culture of the Balinese people in their respective spheres. An autonomous village, as an autonomous village character that can be managed ola and utilizing pakraman village (self-regulations), giving rise to a different interpretation between the adat village itself (Purnamawati, 2018; Purnamawati \& Adnyani, 2019). 
There are two substantially and functionally different village government organizations in Bali Province, namely Customary Village and Service Village. Each has its structure and function so that the nature of community members' attachment to the organization is also different. Customary Village is a territorial unit where its citizens collectively conceptualize and activate religious ceremonies to maintain the sanctity of the village (Sudibia et al., 2017). The main function of the Customary Village is to conceptualize and activate religious ceremonies to maintain the sanctity of the village. Improving the welfare of traditional village manners through indigenous community-based tourism programs is one of the strategies and efforts that can be done by traditional villages by coordinating with village government agencies to improve community welfare. The tourism sector is a labor-intensive sector, very much economic benefit can be generated from this sector such as accommodation, lodging, restaurants, and transportation. Afrizal \& Nazaki (2017) states that the village's authority as a community right property to manage and manage its household or often referred to as a form of genuine autonomy. Several types of generic authority are often discussed: the authority to form and manage self-government systems. Authority to manage local resources (village treasury land, customary land, and customary forest). Authority to make and implement local customary law. Authority to manage and care for local values and culture (including customs). Judicial authority or community justice system, for example in resolving local conflicts.

The customary law community unit takes care of life independently (autonomously), and the authority to take care of their lives independently (autonomy), and the authority to take care of itself is owned since the unity of the customary law community is formed without being given by another person or party. This is where the origin of indigenous villages is said to have genuine autonomy. The Political Direction of the Law of the Province of Bali can be seen in the Regional Long-Term Development Plan of the Province of Bali 2005-2025 which is regulated by Regional Regulation No.6 of 2009. In the direction of the development of Bali, CLCU (Customary Law Community Units) recognition in the development of sustainable tourism is an important point to accelerate the realization of public welfare (Arismayanti et al., 2019). This implies that in every construction of CLCU recognition given access, both the RLTDP and RLTMDP both provide a space for CLCU recognition in the development of sustainable tourism.

The legal politics of indigenous people is contained in Law no. 6 of 2014 concerning Villages. The legal politics of indigenous and tribal peoples are contained in Article 97 paragraphs (1), (2), (3), and (4) which explicitly regulates the recognition of CLCU along with their traditional rights to realize sustainable tourism development. Thus, basing on the RLTDP, RLTMDP, and Law No.6 of 2014 provide clear direction towards the legal politics of CLCU recognition. Normatively the prospect of an Indigenous Village as an autonomous village is very bright. But seen from the social reality, empowerment, preservation, and development of Indigenous Villages in Bali are faced with various problems, obstacles, challenges, and opportunities in the current era of globalization (Budarma \& Suarta, 2017).

Political and legal problems arise when the CLCU recognition is incomplete in Law No.10 of 2009 concerning Tourism and Law No.12 of 2011 concerning the Formation of Laws and Regulations. Not completely intended is that there is no clear regulation related to the procedures and procedures for recognition of CLCU. The ambiguity of these norms is the reason in the future legal politics of the need to construct a new norm with the ideal model of CLCU recognition in sustainable tourism development.

Various groups have estimated that Bali's tourism has approached its saturation point and has been over-exploited (overworked) so that it is feared that it will begin to be abandoned by tourists (Urbanus \& Febianti, 2017). Bali Provincial Regulation No. 4 of 2019 concerning Indigenous Villages in Bali confirms new concepts in terms of strengthening the rights of traditional villages, including in the management of Tourism Villages through Padruwen Indigenous Villages. Padruwen Customary Village is the entire wealth of Customary Village both material and material. A social entity like a traditional village that houses an indigenous community and so on has become a social institution that has a very important position (Arismayanti et al., 2019). They are autonomous institutions with their traditions, customs, and laws that are firmly rooted, and relatively independent from the interference of external power entities. The results of the study by Dewi (2019) found that Tri Hita Karana became the main foundation for the development of a sustainable tourism village in Bali by using the concept of Building Village, where the village as the subject, looks inward by exploring local potential and local wisdom while minimizing external influences. Research by (Irfan \& Suryani, 2017), the development of a tourism village is the main prerequisite as an effort to preserve the unique potential and empowerment in the form of local culture and local wisdom values which tend to be extinct due to being eroded by globalization and entering rural areas.

Based on preliminary research conducted by researchers, there are juridical problems, which have implications for sociological, and philosophical problems because they are based on a study of preliminary findings that some legislation products that do not contain the role of indigenous villages in 
tourism development, especially those related to one element of the traditional village treasury that is culture have not been incorporated into the substance of the regulation of tourism economic resources to support tourism development. This is what later motivated researchers to conduct a study of the Role of Indigenous Villages as Part of CLCU in Tourism Development. The two main issues that are the focus of the study of the authors in this study is the potential of Indigenous Villages in tourism development and the position and function of Indigenous Villages in Bali Province in tourism development.

\section{Methods}

This type of research conducted in the preparation of this dissertation is a type of socio-legal research. This research is a type of legal research that uses the socio-legal approach. Socio-legal studies are not new studies. This interdisciplinary study is a "hybrid" of the large studies of law and the sciences of law from the perspective of the society that was born before. The need to explain legal issues more theoretically meaningfully enriches this study. Meanwhile, practically, this study is also needed to explain the operation of the law in the daily lives of citizens.

The sociolegal approach is carried out with research steps starting from studying the legal text in the meaning of the text of the legislation and seeing the working of law in society. The use of a combination of doctrinal legal research methods and empirical legal research (which borrows social science methods). Furthermore, known as the terminology Sociological Jurisprudence is one of the flows in the Philosophy of Law that grows and develops in the European continent, pioneered by Eugen Erlich.

Adjusting to the problem, this study uses a statutory approach and a case approach. The law approach is carried out to determine whether or not there is the synchronization of regulations or laws, both vertical and horizontal. The case approach in this study is intended to examine legal cases regarding the fulfillment of the rights of the KMHA, especially traditional villages and their supporting communities in tourism development. The source of legal material from normative legal research is the result of research through library research (Diantha, 2017). Legal analysis techniques in the form of legal hermeneutics and analyzed through legal pluralism theory and the concept of recognition of the CLCU.

\section{Results and Discussions}

In Bali, there is village dualism, namely the Desa Dinas and Desa Adat, which have an equally strong existence in the community because both have different functions. Currently, in Bali, there are 1,493 Customary Villages spread across 9 (nine) Regencies in Bali Province (Yanti, 2019). The aim of the Tourism Culture Preservation and Development Program in Indonesia has seen in Law Number 25 of 2000 concerning Social and Cultural Development stipulated that cultural development and tourism are carried out through the Cultural Conservation and Development Program and the Tourism Development Program (Nalle, 2015). The above goal is seen that the tourism industry in Indonesia is developed based on the community, arts, and culture as well as local natural resources (charm) while maintaining the preservation of the local environment.

Furthermore, to realize the objectives of tourism development, the development of tourism villages is still faced with several fundamental issues that are at the root of the problem of disruption of the MHA, especially on the existence of customary villages in the management of potential tourism assets, some of these issues, among others (Antara \& Arida, 2015): (1) There is a duplication of the model and the lack of product differentiation, that the development of a tourism village tends to repeat the products that have been created by the existing tourism village. An interesting example is developing the Baha Tourism Village, Badung Regency, Bali, which instantly modeled the construction of a traditional gate (angkulangkul) made by Penglipuran Village, Bangli Regency, Bali. It could be said to be a deliberate duplication process by ignoring the potential authenticity and uniqueness; (2) There is no standardization of tourism villages, tourism villages appear and develop more because of the 'go along' factor. The emergence of a tourist village thus runs naturally, not through a selection or standardization process; (3) Tourism products are not based on local potential, tourism products that are packaged and offered to tourists in a tourism village are often not based on local potential or the potential of the village concerned. They only follow the trend of products developed in other villages which have already become tourist villages; (4) Access Limitations, several tourism villages that have superior potential are located; (5) Weaknesses in the packaging of tour package products, villages that have great potential to be developed as tourism villages often fail because they cannot package packages in geographically difficult areas that are difficult to reach; (6) Lack of government commitment, cases often emerge, where a village has superior potential and the community has a strong commitment to developing a tourist village; (7) The low quality of local 
human resources, many villages want to develop tourism villages even though they do not have the human resources to manage tourism villages.

The fulfillment of the rights of the LCU to the existence of customary villages and their supporting communities in the management of tourism assets is hampered by problems that originate from the internal village, such as the supra structure of the village (government, regulatory constraints). Model duplication, non-standardization of tourism villages but still permitted to operate without deliberation or involving LCU and lack of government commitment in identifying the potential of indigenous villages and neglect in developing tourism potential management policies, this condition causes LCU to be marginalized from the area of indigenous villages and their natural resources related to the management of tourism assets (Antonov, 2016). Can be analyzed indirectly the occurrence of human rights violations including violations of the rights of the LCU over customary territories and the rights to manage natural resources especially tourism assets. The response to these problems led to the need for protection and fulfillment of the rights of the LCU over customary territories and the right to manage tourism assets by the customary village. The protection and fulfillment of the rights of LCU as human rights is very important with the provisions of Article 28I paragraph (4) of the 1945 Constitution of the Republic of Indonesia. The form of state responsibility by the mandate of the constitution and placing respect for the LCU can be examined philosophically, juridically, and sociologically.

The philosophical essence of fulfilling the welfare level of the LCU, especially traditional villages in the management of tourism assets and supporting elements, basically refers to the value of justice for all Indonesian people. The orientation of sustainable tourism development must aim to improve the level of life with social justice as one of the meanings of the development carried out. The essence and essence of the regulation of human life must be through legislation in the Indonesian Law State that cannot be separated from the basic rules that have been put in the lives of the people themselves. In this connection, the Pancasila as a national legal ideal that has been recognized as the source of all sources of law and the 1945 Constitution of the Republic of Indonesia as the basis of various laws and regulations must be considered in the formation of legislation. Because Pancasila has validated the existence of the LCU in Indonesia and the 1945 Constitution of the Republic of Indonesia has recognized and respected the unity of the LCU and their traditional rights within this framework, the recognition and protection of the existence of the CLCU and its traditional rights over customary territories (land) and the right to manage natural resources, one of which can be a tourism asset in the development of tourism business. The basis for consideration of the drafting of Law Number 10 of 2009 concerning Tourism in the Preamble Considering the letter a, including: "that the state of nature, flora, and fauna, as a gift from God Almighty, as well as ancient relics, historical relics, arts, and culture owned the Indonesian people are the resources and capital of tourism development to increase the prosperity and welfare of the people as contained in the Pancasila and the Preamble of the 1945 Constitution of the Republic of Indonesia ", must provide protection to the community (specifically the LCU) and regulate and recognize the rights of the LCU.

There are several forms of villages in Bali as follows (Gede, 2010): (1) One Desa Dinas has the same area and population as a traditional village, for example in several mountain villages, such as Serahi, Bunutin, Bonyoh, Manik Lui, there is Abang Songan. (2) One Dinas Desa includes several traditional villages such as the Luwus official village consisting of four traditional villages and the Mekar Sari official village consisting of six traditional villages. (3) One Indigenous Village consists of several service villages, generally located in the urban area. For example, the Denpasar Traditional Village, consisting of several service villages; Buleleng Indigenous Village also consists of several service villages and Kelurahan. (4) An official village includes several traditional villages and part of other custom villages. For example, the Ubud village consists of six traditional villages completely in Ubud, one Banjar that customary village to Peliatan.

This study aims to examine the involvement of villages in the development of tourism based on the participation of local communities as members of CLCU. This study is expected to increase the acceleration of tourism development that can embrace all stakeholders to play a strategic role. Indigenous villages try to utilize the authority they have to create prosperous traditional village manners through increasing the standard of living of traditional manners or indigenous people through improving the community-based economy or utilizing the tourism sector based on traditional village manners.

\section{Discussion}

The potential of traditional villages in the form of authority was based on studies from previous research showing that they were not yet capable and maximally carried out by traditional villages, although traditional villages were recognized for their role in the development of cultural tourism in Bali in Bali Province Regulation No. 4 of 2019, has a strong capital of legitimacy through the regulation through local regulations. Customary villages should be able to use their authority to carry out creativity and 
innovation in programs and activities to improve the standard of living of customary village manners. The participation of Indigenous Villages in the management of tourism objects is reflected in the granting of authority granted to Indigenous Villages, in the form of the appointment of staff or human resources who work in tourism objects. It cannot be denied that the tourism sector has a very large role as a force in economic development. Tourism activities provide income for traditional villages to exercise their authority and to develop the potential that exists within their territory.

The regulation on the authority of traditional villages in the regulation in the Regional Government Law is still unclear (blurred norms), where the Regional Government Law does not explicitly explain the rules on tourism management by the Customary Villages. Related to the above, it is necessary to know how to regulate village authority in tourism management. Therefore, to answer the obscurity of the norm, a review of the Regional Government Law was conducted. Through the development of tourism villages, it is expected that equity will occur by the concept of sustainable tourism development. Also, the existence of a tourism village makes tourism products more valuable in a rural culture so that the development of a tourist village is of cultural value without damaging it.

The local community acts as the host and becomes an important factor in the development of the tourism village in all stages starting from the planning, supervision, and implementation stages. In fulfilling the CLCU's right to customary villages in the management of tourism assets and their supporting communities, local wisdom is manifested in the form of myths, legends, customs, traditions, beliefs, reliefs carved into traditional houses or rebuilt, woven cloths and other social organizations. Fulfillment of CLCU's right to customary villages in the management of tourism assets and other supporting communities based on local wisdom is suitable as a foundation in raising awareness that humans are part of nature. The synergy of indigenous villages is related to the management of local tourism potential. The competency to be achieved is to live and practice tourism management wisely and wisely. Achieving this value, local wisdom related to local tourism is needed to be integrated into the regulation of the fulfillment of CLCU rights.

The potential of indigenous villages in tourism development is important when placed based on the belief that traditional villages must know what is needed by traditional village manners in the village territorial area. Essential participation will involve indigenous villages in all stages of development, starting from the planning process, decision making, and supervision of tourism development programs. The participation of a traditional village by involving its supporting elements, that is, the traditional village manners are greatly influenced by the will, opportunity, and ability of the community. Community participation in village tourism planning can encourage them to actively participate in implementation and supervision.

In realizing the vision, it was pursued through 22 (twenty-two) Missions of Bali Development which became the direction of Bali Development policy as the implementation of the Planned Universe Development Pattern. (1) Ensuring the fulfillment of food, clothing, and shelter needs in sufficient quantity and quality for the life of Krama Bali. (2) Achieve food independence, increase the added value and competitiveness of agriculture, and improve the welfare of farmers. (3) Developing affordable, equitable, fair, and quality public health services and supported by the development of a district-based Krama Bali health history system and database. (4) Ensuring the availability of affordable, equitable, fair, and quality education services and implementing 12-year compulsory education. (5) Develop a system of basic education and secondary education based on Hinduism in the form of Pasraman in Pakraman / Customary Village. (6) Developing highly competitive human resources of quality and integrity: quality, professional, and moral and having a strong identity developed based on the values of Krama Bali's local wisdom. (7) Developing a comprehensive and integrated social security system for the life of Krama Bali from birth, growth, and development until the end of his life. (8) Producing a competent, productive, quality, and high competitiveness workforce and expanding access to employment opportunities at home and abroad. (9) Develop a system of social security and labor protection that is comprehensive, easily accessible, quality, and integrated for Krama Bali who works at home and abroad. (10) Promote Balinese culture through enhancing protection, fostering, developing, and utilizing traditional, religious, traditional, artistic, and cultural values of Bali's Krama. (11) Developing the life system of Balinese Krama in a sacred and noetic way based on Sad Kertih's philosophical values namely Atma Kertih, Danu Kertih, Wana Kertih, Segara Kertih, Jana Kertih, and Jagat Kertih. (12) Strengthening the position, duties, and functions of customary villages in organizing Balinese manners including parahyangan, pawongan, and palemahan. (13) Developing new tourism destinations and products based on culture and siding with the people that are integrated between regencies in Bali. (14) Increasing the promotion of Bali tourism at home and abroad in the synergy between regencies/cities in Bali by developing innovations and creativity. (15) Enhance the quality standards of tourism services comprehensively. (16) Build and develop new economic centers by the potential of districts/cities in Bali by empowering local resources to support economic growth in a 
broad sense. (17) Build and develop a culture-based small and medium industry (Balinese branding) to strengthen the Krama Bali economy. (18) Increasing infrastructure development (land, sea, and air) in an integrated manner and connectivity between regions to support economic development and access and quality of public services in Bali. (19) Develop an integrated security system that is supported by human resources and adequate infrastructure to maintain the security of the area and Krama Bali and the safety of tourists. (20) Realizing Balinese Krama life that is democratic and fair by strengthening the legal culture, political culture, and gender equality by taking into account Balinese cultural values. (21) Developing Balinese Krama life arrangements, managing the region, and the environment that is green, beautiful, and clean. (22) Develop a system of effective local governance that is efficient, open, transparent, accountable, and clean and increases integrated public services that are fast, certain, and inexpensive.

The Sustainable Tourism Charter emphasizes that tourism must be based on sustainable criteria which in essence is that long-term ecological development must be supported and tourism must be economically feasible and ethically and socially fair to local communities. Also, the concept of sustainable development includes three components that are interconnected with one another, as follows (Klarin, 2018). First, Ecological Sustainability, means that tourism development is not caused by irreversible changes in an existing ecosystem, and has become a generally accepted dimension since there is a need to protect natural resources from the negative impacts of tourism activities. Second, Social Adaptability, by the group's ability to absorb tourists without causing disharmony in social relations, either between members of the community group with tourists or between fellow members of the group. Third, Cultural Sustainability, in this context assumes that the impact of the presence of tourists to a tourist destination, does not hurt the development of local culture, but the existence of the culture must be maintained for generations to come. Furthermore, to achieve the goal of sustainable tourism development, two approaches are needed about tourism. Hoang et al (2018), show two models of interrelation, among others: First, Horizontal linkage (circle), this approach implies that tourism is a facilitator of various programs and policies that will be implemented.

For the process to be efficient, various supporting policy components are needed to be able to clearly understand the problem, define the development vision and mission, understand the hierarchy of program goals and objectives, and organize the process properly. In this approach tourism is a component of the process that runs parallel to other fields so that collectivity is needed. Second, Vertical Linkage (vertical circle). The purpose of the relationship between these approaches is to find a balance in combining important components of tourism and development activities and 'protecting' various brilliant breakthroughs in decision making. The characteristics of vertical relationships are as follows: First, in this approach, tourism is a part of development that functions as a strategic part of policymaking, so that it is at the top and influences other sectors; Second, the strategic elements of policy planning must include the provision of tourism facilities and infrastructure; Third, the development of special tourism, including accommodation, in various types, hotels, motels, and so on; Fifth, the estimated impact (including carrying capacity studies) of tourism development in terms of the economic, environmental, socio-economic aspects of local communities, culture, and heritage; Sixth, financing, marketing, promotion, and information systems; Seventh, the Tourism Awareness campaign for the community.

The rights of indigenous peoples to customary law areas include the determination of territories, the existence of legal guarantees on land use and space that protect the right of ownership both communally and individually, the existence of legal and political guarantees to protect the sources of life indigenous peoples in the form of water, soil, forest, watersheds and disaster-prone areas into their customary law territories (Priambodo, 2018). Based on Article $18 \mathrm{~b}$ of paragraph (2) the second amendment of the 1945 Constitution of the State of the Republic of Indonesia states: "The State recognizes and respects the unity of indigenous and tribal peoples as long as it is alive and by the development of society and principles Unitary State of the Republic of Indonesia, as governed by law ".

In consideration of Law Number 10 the Year 2009, it is stated: "that the state of nature, flora, and fauna, as a gift from God Almighty, as well as ancient relics, historical, artistic, and cultural heritage of the Indonesian people are resources and development capital tourism for increasing the prosperity and welfare of the people as contained in the Pancasila and Opening of the 1945 Constitution of the Republic of Indonesia, must provide protection to CLCU and regulate and recognize their rights. Regarding the implementation of the authority for implementing tourism-related to Tourism Villages, Law No. 10 of 2009 concerning Tourism (hereinafter referred to as the Tourism Act) is not the only account even though it is the first reference. Because regarding how the provisions in the Tourism Act are implemented in the region, it depends on the scope of authority granted by the law to the regions in tourism affairs.

Article 29 paragraph (3) letter c Government Regulation Number 50 of 2011 concerning the National Tourism Development Master Plan for 2010-2025 (hereinafter referred to as PP RIPKN) 
stipulates that strategies for increasing the potential and capacity of local resources, one of which is by developing the potential of local resources through the tourist village. The Bali Tourism Development Master Plan is regulated in the Bali Provincial Regulation Number 10 of 2015 concerning the Bali Provincial Tourism Development Master Plan for 2015-2029 (hereinafter referred to as the Bali RIPPARDA Regional Regulation) as a follow-up to the mandate of Article 4 (2) PP RIPKN. Regarding the concept of sustainability currently being applied in various development sectors, tourism is no exception. The purpose of the application of the concept of sustainability in tourism is nothing but a positive impact or benefit on the environment and economy of indigenous villages, as well as a positive impact on the social and cultural environment in the region.

\section{Conclusion}

The traditional village is the foundation of Balinese culture which is the main attraction of Bali tourism. The Local Regulation of Customary villages is specifically regulated by the authority of the Customary villages in the management of tourism destinations especially the tourism villages and it is clearly stated that Adar Village has the authority in the management of the Tourism Village as long as the main object is the Padruwen Customary villages which is the right of the origin and local scale. If related to the tourism development process, based on Regional Regulation No. 4 of 2019 concerning Customary Villages In Bali, the authority of Customary Villages in the management of tourist villages is based on customary values, religion, traditions, arts, and culture as well as local wisdom on indigenous Padruwen villages which in their implementation involve the participation of local customary village communities. Sociologically, Customary Villages are always involved in the management of Padruwen Customary Villages as Tourism Villages can be managed by Customary Villages if they are indigenous and local-scale, as contained in Article 25 of the Customary Villages Local Regulation. Then give direction to the role of Indigenous Villages in Bali in tourism development. For academics and legal drafter, recommendations resulting from this research can be used in the drafting of laws and regulations that regulate the role of customary law as part of CLCU in tourism development. The theoretical benefit is that the results of this study are beneficial to the development of legal science related to CLCU recognition in tourism development. In practical terms, normalizing CLCU recognition as well as giving an understanding to traditional villages is for CLCU recognition in tourism development.

\section{References}

Adnyani, N. K. S., \& Purnamawati, I. G. A. (2020). Pengarusutamaan Gender Krama Istri (Warga Perempuan) dalam Hukum Adat Bali. Pandecta Research Law Journal, 15(1), 26-43. https://doi.org/10.15294/pandecta.v15i1.18422.

Afrizal, \& Nazaki. (2017). Peran Pemerintah Kabupaten Bintan dalam Meningkatkan Kemampuan Desa Terhadap Pengelolaan Kewenangan (Studi Pelaksanaan Kewenangan Desa Malang Rapat Dalam Mengelola Potensi Wisata). Jurnal Selat, 5(1), 88-104.

Antara, M., \& Arida, N. S. (2015). Panduan Pengelolaan Desa Wisata Berbasis Potensi Lokal. Denpasar, Bali.

Antonov, M. (2016). The Legal Conceptions of Hans Kelsen and Eugen Ehrlich: Weighing Human Rights and Sovereignty (Law No. WP BRP 62/LAW/2016). Saint Petersburg (Russia).

Arismayanti, N. K., Sendra, I. M., Suwena, I. K., Budiarsa, M., Bakta, I. M., \& Pitana, I. G. (2019). Tourism Villages' Development in Bali, Mass or Alternative Tourism? Journal of Tourism and Hospitality Management, 7(2), 117-139. https://doi.org/10.15640/jthm.v7n2a11.

Arjawa, I. G. P. B. S., \& Jayantiari, I. G. A. M. R. (2017). Democratic values in Balinese traditional society: Analysis of the making and the content of Desa Pakraman's awig-awig. Masyarakat, Kebudayaan Dan Politik, 30(4), 428-436.

Budarma, I. K., \& Suarta, K. (2017). The Role of Local Value in Global Sustainable Tourism Development Paradigm. The Case of Tourism in Bali. Journal of Business on Hospitality and Tourism, 2(1), 234249. https://doi.org/10.22334/jbhost.v2i1.58.

Chang, H.-M., \& Huang, H.-C. (2014). A Study of Indigenous Tourism Development- Case by Tamalung Tribe in Taiwan. The Journal of International Management Studies, 9(2), 87-94.

Dewi, P. S. T. (2019). Model of Sustainable Tourism Village Development in Bali (Case Study: OMunity Bali in Sudaji Village, Sawan Sub-district, Buleleng District). KnE Social Sciences. 
https://doi.org/10.18502/kss.v3i21.5001.

Diantha, I. M. P. (2017). Metodologi Penelitian Hukum Normatif dalam Justifikasi Teori Hukum (1st ed.). Jakarta: Kencana.

Gede, P. I. (2010). Tri Hita Karana-The Local Wisdom of the Balinese in Managing Development. Trends and Issues in Global Tourism, 139-150. https://doi.org/10.1007/978-3-642-10829-7_18.

Hoang, V. H., Tran, M. D., Tran, T. V. H., \& Hoang, V. H. (2018). Regional Linkage in Tourism Development of Vietnam. Preprints, 1(1), 1-15. https://doi.org/10.20944/preprints201807.0578.v1.

Irfan, M., \& Suryani, A. (2017). Local Wisdom Based Tourist Village Organization in Lombok Tourist Area. International Journal of English Literature and Social Sciences, 2(5), 73-82. https://doi.org/10.24001/ijels.2.5.10.

Kent, G. (1981). Community-Based Development Planning. Third World Planning Review, 3(3), 313-326. https://doi.org/10.3828/twpr.3.3.q07416r622q2uj02.

Klarin, T. (2018). The Concept of Sustainable Development: From its Beginning to the Contemporary Issues. Zagreb International Review of Economics and Business, 21(1), 67-94. https://doi.org/10.2478/zireb-2018-0005.

Mansuri, G., \& Rao, V. (2004). Community-Based and -Driven Development: A Critical Review (World Bank Policy Research Working Paper No. 3209).

Nalle, V. I. W. (2015). The Relevance of Socio-Legal Studies in Legal Science. Mimbar Hukum, 27(1), 179192.

Priambodo, B. B. (2018). Positioning Adat Law in the Indonesia's Legal System: Historical Discourse and Current Development on Customary Law. Udayana Journal of Law and Culture, 2(2), 140-164. https://doi.org/10.24843/UJLC.2018.v02.i02.p02.

Purnamawati, I. G. A. (2018). Dimensi Akuntabilitas dan Pengungkapan pada Tradisi Nampah Batu. Jurnal Akuntansi Multiparadigma, 9(2), 312-330. https://doi.org/10.18202/jamal.2018.04.9019.

Purnamawati, I. G. A., \& Adnyani, N. K. S. (2019). Peran Komitmen, Kompetensi, dan Spiritualitas dalam Pengelolaan Dana Desa. Jurnal Akuntansi Multiparadigma, 10(2), 227-240. https://doi.org/10.18202/jamal.2019.08.10013.

Resen, M. G. S. K., \& Dyatmikawati, P. (2016). The Legal Status of Established Businesses in the Pakraman Village (From The Perspective of Customary Law in Bali Province). International Journal of Business, Economics and Law, 9(4), 1-3.

Sudibia, I. K., Sintaasih, D. K., Yuliarmi, N. N., \& Marhaeni, A. A. I. N. (2017). Empowerment of Desa Adat Community to Support the Existence of Village Credit Institutions in Bali Province. Man In India, 97(11), 357-372.

Urbanus, I. N., \& Febianti. (2017). Analisis Dampak Perkembangan Pariwisata terhadap Perilaku Konsumtif Masyarakat Wilayah Bali Selatan. Jurnal Kepariwisataan Dan Hospitalitas, 1(2), 118133.

Yanti, A. A. I. E. K. (2019). Kewenangan Desa Adat dalam Pengelolaan Kepariwisataan Budaya Bali dalam Perspektif Peraturan Daerah Nomor 4 Tahun 2019 Tentang Desa Adat. Jurnal Hukum Saraswati, 1(1), 48-60. 